\title{
Determinants of HIV Infection in Nigeria: A synthesis of the literature
}

Olatunji Joshua Awoleye ${ }^{1}$ and Chris Thron $^{2}$

${ }^{1}$ Independent Monitoring and Evaluation (IMEP), $2^{\text {nd }}$ Floor, NEXIM House, Central Business District, Abuja, Nigeria (olatunji.joshua@gmail.com)

${ }^{2}$ Department of Mathematics, Texas A\&M University-Central Texas, 1001 Leadership Place, Killeen TX 76549 USA (hㅏon@,tamuct.edu)

Correspondence to: Email: olatunji.joshua@gmail.com, Tel: +234-8136323807

\begin{abstract}
Background: Nigeria has an estimated 3.5 million HIV positive individuals, ranking third worldwide. This study analyzed the determinants of HIV infection to improve HIV programming in Nigeria and developing countries.

Methodology: The methodology used was a literature review of grey and electronic databases of reviewed journals, and application of Dahlgren and Whitehead (1991) determinants of health model. A total of 45 publications (21 reports and 24 articles were reviewed).

Results: New infections are emerging at increasing rates among individuals engaging in sexual relationships such as men having sex with men (MSM) and female sex work (FSW). The level of political commitment to HIV control is extremely low: currently, the government of Nigeria provides less than 10 percent of the funding for HIV control efforts in Nigeria, the rest coming from foreign sources and private sectors. Political, work environment, gender, healthcare service and lifestyle determinants are predominant over others.

Conclusion: HIV control in Nigeria is financially over-dependent on foreign interventions. Political actions are required to address sexual orientations. Most-at-risk populations require education, legal requirements, and healthcare services in order to minimize new infection.
\end{abstract}

Keyword: HIV, Infection, Determinant, Dahlgren and Whitehead

\section{INTRODUCTION:}

The human immunodeficiency virus (HIV) is a retrovirus that infects cells of the immune system, destroying their function. Sub-Saharan Africa continues to bear a disproportionate share of the global HIV burden. In mid-2010, about 68 percent of all people living with HIV resided in sub-Saharan Africa, a region with only 12 percent of the global populations (UNAIDS 2011).

It was estimated that 3.5 million people are living with HIV (PLWHIV) in Nigeria in 2012, ranking the country third among countries with the highest burden of HIV infection in the world after India and South Africa (NARHS 2012). Figure 1 shows Nigerian sero-prevalence rates during the period from 1991 to 2012. National prevalence is gradually declining according to NARHS, which measured a 3 percent 
prevalence in its 2012 survey as against 3.6 percent in 2007. NARHS 2012 also provided information for several demographics as follows. Urban prevalence was 3.2 percent, compared with 3.6 percent for rural areas. Among Nigeria's six geopolitical zones, South South had the highest prevalence at 6.3 percent, while South East had the lowest at 1.3 percent. The age groups with highest and lowest prevalence were 35-39 (3.6 percent) and 15-19, 40-44 and 45-49 (2.7 percent), respectively. There was no significant difference between female ( 3.4 percent) and male (3.3 percent) prevalence.

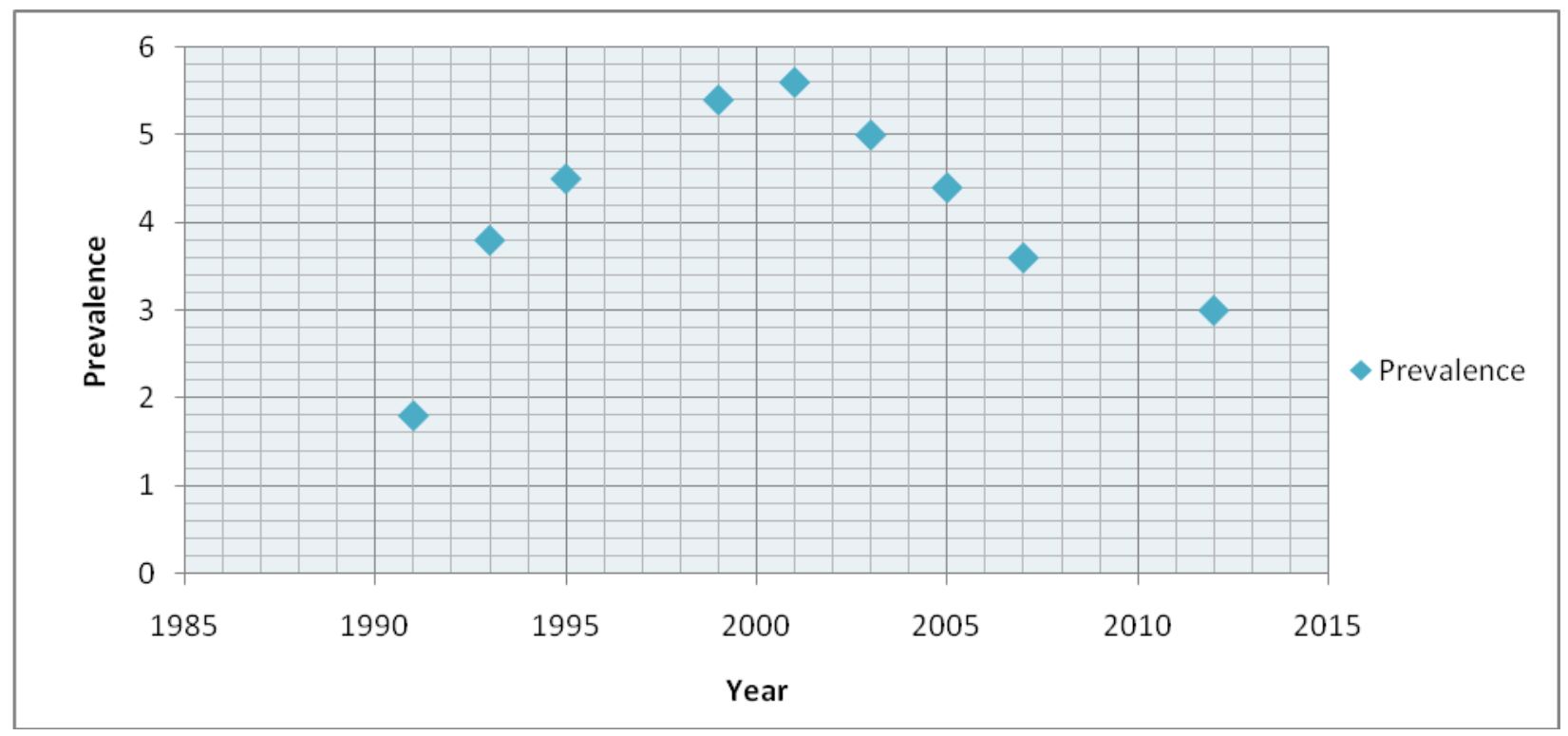

Figure 1 Trends in national HIV sero-prevalence rate, Nigeria, 1991-2012 (Source: NACA, 2009).

There has been a shift from viewing HIV risk as predominantly an individual behavior to viewing it as impacted by social, economic, political, and/or cultural determinants (Weine and Kashuba, 2012). Several social and economic factors have been shown to have significant impact on prevalence. According to NARHS (2012), prevalence was higher (3.0 percent and above) among people with primary and higher education compared with people who had no formal education (2.5 percent) or among Qur'anic (2.4 percent). Similarly, out of five wealth categories a prevalence of about 3.6 percent was recorded in the two wealthiest categories as compared to 2.9 percent for the poorest. NDHS 2008 reveals that respondents with highest wealth quintile had highest comprehensive knowledge that condom use will protect against HIV and that HIV-negative faithful partner can reduce chances of getting the AIDS virus. However, risky sexual practices are higher among men and women in the highest wealth quintile. By marital status, widows had the highest prevalence (6.2 percent).

A number of studies have focused on special subpopulations. According to IBBSS (2010), HIV prevalence was highest among brothel-based female sex workers (BBFSW) (27.4 percent), followed by 21.7 percent and 17.2 percent among non-brothel-based female sex workers and men who have sex with men (MSM), respectively. Other subpopulations include: injecting drug users (IDU) (less than 5 percent), transport workers (2.4 percent), military (2.5 percent) and police (2.6 percent). According to Muhammad et al (2010) among male prison inmates the age groups with highest and lowest prevalence were 10-20 (7.1 percent) and $41-50$ years (4.0 percent), respectively.

The leading route of HIV transmission in Nigeria is heterosexual intercourse, accounting for over 80 percent of new infections, followed by mother-to-child transmission. Of new adult infections, 38 percent can be attributed to IDU, MSM and BBFSW (who may get infected by their partners), which constitute 3.5 
percent of the adult population (FMOH, 2010 and NSP 2010-2015). Additionally, IDU and MSM are growing in importance (NSP 2010-2015).

Some studies have focused on the social and economic impacts resulting from high HIV infection rates. A study conducted by Risley, Drake \& Pundy (2012) revealed an estimated 340,940 Nigerian teachers living with HIV, which negatively impacts the quality of education since PLWHIV experience increased illness and absenteeism from work (FHI, 2004). A study conducted by Canning et al (2006) details the serious economic challenges that HIV-affected households in Nigeria are likely to face compared to their HIVnegative counterparts. These include the likelihood of substantial income losses, increased burden of caregiving, as well as higher out-of-pocket health care spending.

The need to study the determinants of HIV infection in Nigeria arose due to the spread of the virus particularly through marginalized social groups such as IDU, MSM, and FSW.

\section{Objective:}

To analyze the determinants of HIV infection in Nigeria using Dahlgren and Whitehead's model of determinant of health; based on review of journal articles published between 2000 and 2015.

\section{METHODOLOGY:}

A literature review of relevant material on HIV and determinants of health was conducted. PubMed (Medline), Google Scholar, and e-Library were the search engines used. The search strategy paired the search term "nigeria hiv infection" with various search terms related to the different factors indicated by Dahlgren and Whitehead's model. A comprehensive list of the search terms used is given in the Appendix. Reference sections of reviewed literature were also examined to identify additional sources.

Nine country-specific reports on HIV were reviewed: NDHS 2008, NSF 2010-2015, IBBSS 2008 and 2010, NARHS Plus 2007 and NARHS Plus II 2012, NACA report, UNAIDS, and PEPFAR (see "References" section for complete citations). Cited articles were searched for references to additional studies, and priority was given to primary source articles. A total of 45 publications were reviewed, including the nine reports listed above.

Delimiter: 2000 - 2015 English language journal articles, books and report were examined. Reason: within the chosen year range there were substantial and related materials

Determinants identified were analyzed according to Dahlgren and Whitehead's model of determinants of health, depicted in Figure 2 below. Not all of these determinants were investigated, due to non-availability of relevant articles. 


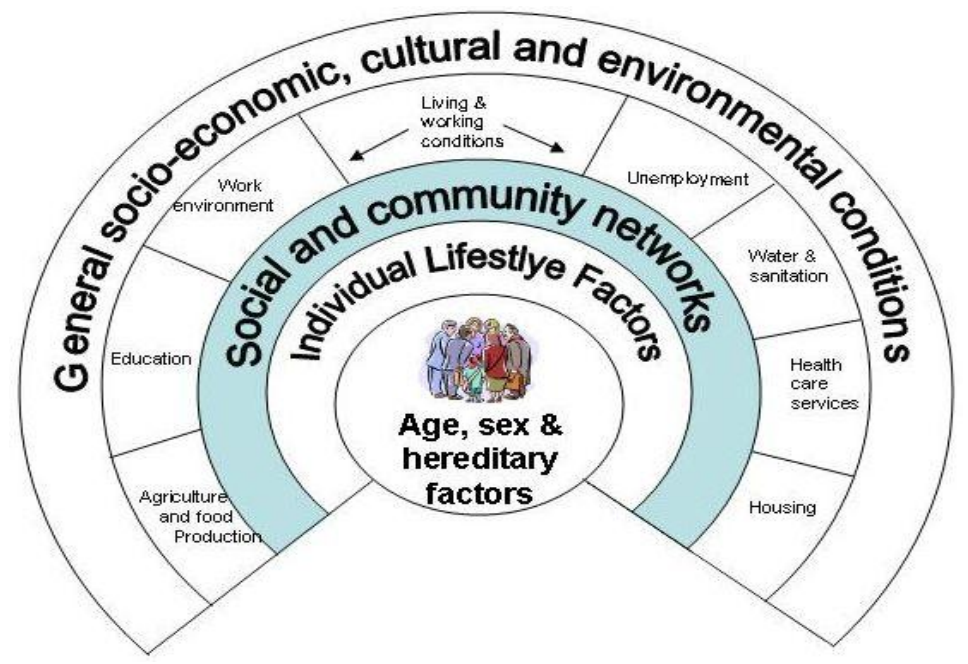

Figure 2: Dahlgren and Whitehead's model of determinants of health (from www.healthknowledge.org.uk)

\section{RESULTS}

\section{Political}

The National Agency for the Control of AIDS (NACA) is at the apex of linked government institutions in the multisectoral HIV/AIDS response architecture; it is mandated to provide overall coordination of the national response. However, the financial commitment from the Nigerian government has been low, and funding is externally dependent. In 2007 and 2008, 85.4 percent and 92.3 percent (respectively) of funding for HIV/AIDS activities in Nigeria came from international organizations (FGN, 2013).

At the state and local government levels, there are critical shortfalls in managerial capacity. Political interference in coordination structure distorts relationships and linkages of institutions at several levels (NACA, 2005). Examples of adverse political influence include the overconcentration of HIV prevention efforts in urban communities, as against rural where knowledge is grossly inadequate; and the inadequate level of programme implementation focusing on youth categories such as in-school, out-of-school and students at higher learning institutions (NACA, 2009).

Little progress has been made on the implementation of National HIV/AIDS policy which also includes HIV/AIDS workplace policy. This encompasses rights of employees particularly PLWHIV and their families, such as issues of confidentiality, healthcare, testing, benefits and discrimination due to stigma (FGN, 2009). Gender inequities in HIV programming (PEPFAR operation plan report, 2012) are not surprising, given the gender inequity that is prevalent in Nigerian public service.

\section{Socioeconomic}

Even with subsidies and free healthcare services such as HIV counseling and testing, antiretroviral therapy and care from support groups, direct and indirect annual per capita income losses from ill health for PLWHIV were estimated at 21,589 naira (U.S. \$116), as compared to 3,853 naira (\$21) for HIV negative individuals (Mahal et al 2004). Similarly, the annual hospitalization rate is 27.04 percent for PLWHIV as against 4.44 percent for HIV negative persons. Frequency of illness in PLWHIV is 4 times higher than for HIV negative persons. Annual estimated healthcare expense for PLWHIV is 10,729 Naira (\$58) per capita; 
versus 1,329 Naira (\$7) for HIV negative persons (Mahal et al 2004). Inability of infected persons to meet socioeconomic demands in Nigeria contributes to the spread of the infection.

\section{Cultural practice}

Female genital cutting (FGC) includes procedures that intentionally alter or cause injury to the female organs for non-medical reasons (WHO, 2013). Findings from NARHS 2005 shows that female genital cutting is more prevalent in the southern part of Nigeria than the northern part, with South West and South East each recording over fifty percent of the females circumcised (see Table 5 in the Appendix). According to UNICEF 2010, FGC in Nigeria is often carried out by traditional birth attendants using unsanitary knives and other sharp instrument in an unhygienic conditions which could transmit HIV. In addition, Monjok, Essien \& Laurens (2007) illustrated how FGC increases risk of HIV infection.

Similarly, a study conducted by Ugwu (2009) describes harmful traditional practices such as polygamy and wife inheritance, facial marking/tattooing (the use of contaminated instrument increases risk of infection) and ghost marriage (in which a deceased husband's relative steps in as sexual partner for the widow). Women due to culture or gender inequalities could not negotiate condom use with their husbands or sex partners- this fact should be interpreted in light of findings from NARHS Plus II 2012 that HIV infection is significantly higher ( 5 percent) among respondents that reported not using condoms. The practice of sex in exchange for gifts also promotes higher risk of HIV infection: the risk was more pronounced for males in rural areas, and for females in urban areas (NARHS Plus II 2012).

\section{Work environment}

Work environment including brothels constitute one of the highest environmental risks for HIV infection. A study on condom use rate in brothels in Nigeria conducted by Anyanti et al (2004) reveals that only 57 percent of BBFSW used condoms consistently with all clients. Adherence to condom use depended on the level of intimacy with the sex partner, and the amount paid by the client for sex.

According to Aisien and Shobowale (2005), exposures of healthcare workers to blood-borne pathogens including HIV persist due to manipulative use of needles from strings; only 20.2 percent use 'hand-free' technique for disposing of instruments during surgical procedures.

A study on HIV infection by Azuonwu and Obire (2011) conducted among patients at the Nigeria army hospital, Air force clinic and Police clinic in the Niger Delta of Nigeria shows that HIV prevalence was highest among Air Force personnel (20 percent) while Army and Police were 12 percent respectively. The study also showed slightly higher HIV prevalence amongst female (16.7 percent) than male (14.3 percent) counterparts, although the difference was not statistically significant.

Aniebue and Aniebue (2011) reported that HIV screening is still low amongst Nigerian long distance truck drivers (LDTD), despite their high-risk sexual conduct. Also, Sunmola (2010), shows that only 32.3 percent of LDTD reported ever used a condom in sexual relationships.

\section{Education}

NDHS 2008 shows that among women and men of age 15-49, those with higher education engaged in higher levels of high-risk sexual behavior in the previous year. NARHS Plus II 2012 shows a similar correlation between higher education and higher HIV prevalence. Therefore, acquired knowledge does not inhibit infection, but right application of knowledge gained. 


\section{Unemployment}

According to Agaba et al 2014, among socio demographic, risk and biological parameters of HIV patients who present themselves for care and treatment, unemployment status ranked one of the highest in late presentation (84.3 percent) and in advanced HIV disease (61.4 percent). Unemployment (34 percent) was also identified as one of key demographic factors that influence spread of the infection (Desilva et al 2008).

\section{Health care service}

BBSW and MSM constitute key most at-risk populations (MARP) in the spread of HIV infection in Nigeria (IBBSS 2010). MSM behavior is seen as a taboo in Nigeria, and is prohibited by law (Allman et al 2007). Therefore, in health services there is stigmatization, and there is also self-stigma by MSM themselves and therefore less use of health care.

One author's (Awoleye J.O.) experience as a research coordinator for Global Fund Round 5's HIV counseling and testing (HCT) component confirms that HCT is the entry point for client's knowledge of HIV status which invariably leads to treatment for positive patients. But because of stigmatization and discrimination, HCT service points at health centers are shunned by many that might benefit. The poor thus go without testing, while the rich travel abroad for testing and treatment that they could obtain in Nigeria. A study by Reis C, et al (2005) reveals that health professionals display discriminatory attitudes and unethical behaviour towards patients with HIV, including denial of care and breach of confidentiality. Faced with these possible consequences, people prefer to remain untested, thereby increasing the infection rate.

In Nigeria, traditional birth attendants (TBA) play a significant role in the delivery of babies. However, over 22 percent of TBAs proffer unprofessional methods for prevention of mother to child transmission (MTCT) while only 34.3 percent show interest in knowing HIV status of their pregnant patient (Balogun and Odeyemi 2010).

\section{Social Network}

NACA 2005 indicates that some of the critical indicators of the social determinant of the epidemic are: stigmatization of and discrimination against people living with HIV (PLWHIV). Also, a study conducted by Obi, Ifebunandu \& Onyebuchi (2010) shows that the HIV-positive group had more divorced/separated and widowed/widower individuals than the HIV-negative group. As a result of these, PLWHIV will not want to disclose their status, thereby increasing the possibility of infection.

\section{Sex and Gender}

In Nigeria, gender roles are in every sector which increases or reduces chances of HIV infection. Particularly, women are vulnerable to the infection because of factors relating to their procreation and most often subordinate position in society. They typically lack equal access to education, health, training, independent income, property and legal rights which have serious implications for their right to access to knowledge on HIV/AIDS. These measures can be taken to prevent transmission of the HIV infection, as well as their ability to protect themselves (NSF 2010-2015). 
One author's (Awoleye J.O.) experience in HIV counseling and testing (HCT) research shows that women are motivated to undertake HCT before delivery, due to their concern for their babies. This observation supports the FMOH 2006 report that the results of periodic national surveys among ante-natal clinic attendees show a progressive increase in the adult HIV sero-prevalence rate. Similarly, a study by Akhigbe, Bamidele \& Abodunrin (2010) illustrates that there is a marginal gender preference in the prevalence of HIV seen in females due to a higher number of the gender utilizing the HIV counseling and testing (HCT) service.

A qualitative study conducted by Mbonu, Borne \& Vries documents significant differences in attitudes towards HIV-positive individuals based on the infected person's sex. Typically HIV-positive women are blamed and labeled as "flirts"; while HIV-positive men are excused, and their infection is attributed to nonsexual causes such as a haircut (Mbonu, Borne \& Vries, 2010: 6).

NARHS Plus II 2012 shows that among women with symptoms of STI (including HIV) 15.8 percent have never married, as compared to 6.4 percent for their male counterparts. This can be attributed to inadequate knowledge of STIs among women as compared to men, as well as the vulnerability (eg. procreation) of women (NARHS Plus II 2012).

Male circumcision (MC) has been practiced for centuries. In resource-poor settings, most circumcisions are still done outside the formal health sector as a rite of passage into adulthood or as a religious observance (WHO report 2006). A study conducted by Illiyasu et al (2012) reveals that 368 of 375 respondents reported being circumcised. The majority (97.8 percent) favour continuation of the practice, while approximately 73 percent of the respondents agreed that circumcised men still need to employ condoms during sex for protection against STIs, including HIV. A total of 22.1 percent respondents pointed out problems associated with the availability and the standardization of circumcision services at health facilities, which explains widespread reliance on traditional circumcisers (see Table 3 in the Appendix).

\section{Individual lifestyle}

Sexual habits are decisive determinants of the risk of HIV infection. According to IBBSS Nigeria (2010), the HIV prevalence among MSM is 17.2 percent. Ankomah et al (2013) reported that in Nigeria, as in many other countries where HIV is transmitted mostly through heterosexual activities, the risk of transmission of HIV is largely determined by sex outside stable relationships. For individuals engaging in such practices, the risk is heightened when no protection is used. Thus the authors concur with Ankomah A. et al (2013) that promotion of condom use for those engaging in higher-risk sexual activities should therefore be a major preventive strategy (see appendix for Tables $1 \& 2$ ).

\section{CONCLUSION/DISCUSSION}

The result of analysis identified political, work environment, gender, healthcare service and lifestyle determinants as predominant over others. In Nigeria, there are HIV control political structures at all Government levels (Local, State, and Federal) established to model identified determinants of health through comprehensive HIV control programmes including behavioral change communications and healthcare services. However, effectiveness has been limited due to political interference and inadequate political will as evidenced by underfunding by the government. 
Determinant such as health care service for MARP are limited due to stigma, discrimination and recent prohibition of MSM in Nigeria. Despite the legal status of MSM, its continued presence within society is documented by research (IBBSS), and should not be ignored. This appeared like a contradiction as they have network and meeting place. . MSM also contributes to HIV prevalence among heterosexuals, due to bisexual behavior.

Infection through work environment would have been minimized with adherence by employers to a national HIV workplace policy. Unfortunately some employers especially in the private sector ignored the policy such that they carry out mandatory pre-employment and employment HIV testing. Also, FSW either brothel-based or non-brothel is not considered as work due to associated stigma and they contribute to infection in Nigeria.

The promotion of condom use is one strategy that could significantly decrease infection rates. No research was found on the use of female condoms, but awareness and utilization are limited in Nigeria.

Finally, the study reveals that attention needs to be paid to predominant determinants as identified above. More political actions are required including financial commitment from each level of Government to empower coordinating agencies. To prevent MTCT of HIV at health facilities and TBAs, multistakeholder approaches are required.

\section{Limitations}

Dahlgren and Whitehead's determinant of health model was helpful in suggesting possible determinants of infection. However, not all of these factors were used due to non-availability of related articles. Furthermore, this study is restricted to factors designated in the model, and does not consider the possibility of other factors.

\section{Contributions}

OJA conducted journal article and report collections and drafted the initial manuscript. CT contributed to sourcing of journals and review of article. And International course in health development of the Royal Tropical Institute Amsterdam, The Netherlands approved the model for analysis.

\section{Conflict of interest}

The author declares no conflict of interest

\section{ACKNOWLEDGEMENT}

This study was supervised by the International course in health development of the Royal Tropical Institute, Amsterdam, The Netherlands. And National Agency for the Control of AIDS (NACA) in Nigeria made available national reports for the study. 
APPENDIX

Search strategies used for PubMed (Medline)

Key words: 1) nigeria hiv infection AND gender norms

(("nigeria"[MeSH Terms] OR "nigeria"[All Fields]) AND ("hiv infections"[MeSH Terms] OR ("hiv"[All Fields] AND "infections"[All Fields]) OR "hiv infections"[All Fields] OR ("hiv"[All Fields] AND "infection"[All Fields]) OR "hiv infection"[All Fields])) AND (("sex"[MeSH Terms] OR "sex"[All Fields] OR "gender"[All Fields] OR "gender identity"[MeSH Terms] OR ("gender"[All Fields] AND "identity"[All Fields]) OR "gender identity"[All Fields]) AND norms[All Fields]) AND ("2003/10/07"[PDat] : "2013/10/03"[PDat]).

\section{2) nigeria hiv infection AND age factor}

("nigeria"[MeSH Terms] OR "nigeria"[All Fields]) AND ("hiv infections"[MeSH Terms] OR ("hiv"[All Fields] AND "infections"[All Fields]) OR "hiv infections"[All Fields] OR ("hiv"[All Fields] AND "infection"[All Fields]) OR "hiv infection"[All Fields])) AND ("age factors"[MeSH Terms] OR ("age"[All Fields] AND "factors"[All Fields]) OR "age factors"[All Fields] OR ("age"[All Fields] AND "factor"[All Fields]) OR "age factor"[All Fields]) AND ("2000/01/01"[PDAT] : "2013/12/31"[PDAT]).

\section{3) nigeria hiv infection AND (social support or social network)}

(("nigeria"[MeSH Terms] OR "nigeria"[All Fields]) AND ("hiv infections"[MeSH Terms] OR ("hiv"[All Fields] AND "infections"[All Fields]) OR "hiv infections"[All Fields] OR ("hiv"[All Fields] AND "infection"[All Fields]) OR "hiv infection"[All Fields])) AND ("social support"[MeSH Terms] OR ("social"[All Fields] AND "support"[All Fields]) OR "social support"[All Fields] OR ("social"[All Fields] AND "network"[All Fields]) OR "social network"[All Fields])

\section{4) nigeria hiv infection AND education}

(("nigeria"[MeSH Terms] OR "nigeria"[All Fields]) AND ("hiv infections"[MeSH Terms] OR ("hiv"[All Fields] AND "infections"[All Fields]) OR "hiv infections"[All Fields] OR ("hiv"[All Fields] AND "infection"[All Fields]) OR "hiv infection"[All Fields])) AND ("education"[Subheading] OR "education"[All Fields] OR "educational status"[MeSH Terms] OR ("educational"[All Fields] AND

"status"[All Fields]) OR "educational status"[All Fields] OR "education"[All Fields] OR "education"[MeSH Terms])

\section{5) nigeria hiv infection AND socioeconomic}

(("nigeria"[MeSH Terms] OR "nigeria"[All Fields]) AND ("hiv infections"[MeSH Terms] OR ("hiv"[All Fields] AND "infections"[All Fields]) OR "hiv infections"[All Fields] OR ("hiv"[All Fields] AND "infection"[All Fields]) OR "hiv infection"[All Fields])) AND socioeconomic[All Fields]

\section{6) nigeria hiv infection AND politics}

("hiv"[MeSH Terms] OR "hiv"[All Fields]) AND ("nigeria"[MeSH Terms] OR "nigeria"[All Fields]) AND ("politics"[MeSH Terms] OR "politics"[All Fields])

\section{7) nigeria hiv infection AND government}

("hiv"[MeSH Terms] OR "hiv"[All Fields]) AND ("nigeria"[MeSH Terms] OR "nigeria"[All Fields]) AND ("government"[MeSH Terms] OR "government"[All Fields]) 


\section{List of Tables}

Table 1 (Ankomah A. et al 2013)

Demographic characteristics of men who engage in extramarital relationships

\begin{tabular}{|l|l|l} 
Variables & Frequency $\mathrm{n}=642$ & Percentage \\
\hline
\end{tabular}

Age of respondents (years)

\begin{tabular}{|l|l|l|}
\hline $15-19$ & 16 & 2.5 \\
\hline $20-24$ & 59 & 9.2 \\
\hline $25-34$ & 254 & 39.6 \\
\hline $35-49$ & 261 & 40.7 \\
\hline $50-64$ & 52 & 8.1 \\
\hline
\end{tabular}

Condom use during last extramarital sex

\begin{tabular}{|l|l|l|}
\hline Did not use condom & 345 & 53.7 \\
\hline Used condom & 297 & 46.3 \\
\hline
\end{tabular}

Education level

\begin{tabular}{|l|l}
\hline No formal education & 52 \\
\hline Primary &
\end{tabular}

Primary

Secondary and higher

\begin{tabular}{|l|l}
\hline 52 & 8.1 \\
\hline 203 & 31.6 \\
\hline 387 & 60.3 \\
\hline
\end{tabular}

\section{Religion}

\begin{tabular}{|l|l|l|}
\hline Islam & 191 & 29.8 \\
\hline Christianity & 424 & 66 \\
\hline Traditional/others & 27 & 4.2 \\
\hline
\end{tabular}

Ethnicity

\begin{tabular}{|l|l|l|}
\hline Hausa & 46 & 7.2 \\
\hline Igbo & 62 & 9.7 \\
\hline Yoruba & 191 & 29.8 \\
\hline Others & 343 & 53.4 \\
\hline Residence & \multicolumn{2}{|l|}{} \\
\hline Rural & 398 & 62 \\
\hline Urban & 244 & 38 \\
\hline Multiple nonspousal sex & & \\
\hline
\end{tabular}




\begin{tabular}{|c|c|c|}
\hline No & 317 & 58.4 \\
\hline Yes: have sex with nonspouse & 325 & 41.6 \\
\hline \multicolumn{3}{|l|}{ Sex in exchange for gift } \\
\hline Never had sex for gift & 479 & 74.6 \\
\hline Have had sex for gift & 163 & 25.4 \\
\hline \multicolumn{3}{|l|}{ Alcohol consumption } \\
\hline Every day & 89 & 13.9 \\
\hline Once a week or less & 267 & 41.6 \\
\hline Others & 286 & 44.5 \\
\hline \multicolumn{3}{|c|}{ Away from home for more than 1 month in the last 12 months } \\
\hline No & 370 & 57.6 \\
\hline Yes & 272 & 42.4 \\
\hline \multicolumn{3}{|c|}{ Do you agree or disagree that condoms are easy to obtain? } \\
\hline Disagree & 123 & 19.2 \\
\hline Agree & 519 & 80.8 \\
\hline
\end{tabular}

(Ankomah A. et al 2013)

Table 2 (Ankomah A. et al 2013)

\begin{tabular}{|c|c|c|c|c|}
\hline \multicolumn{5}{|c|}{ Bivariate analysis of condom use in extramarital sex } \\
\hline & \multicolumn{2}{|c|}{$\begin{array}{l}\text { Condom use in } \\
\text { extramarital sex }(\%)\end{array}$} & \multirow[t]{2}{*}{ Total } & \multirow[t]{2}{*}{$\begin{array}{l}P \text {-value } \\
\text { from } \chi^{2}\end{array}$} \\
\hline & $\begin{array}{l}\text { Used } \\
\text { condom }\end{array}$ & Did not use & & \\
\hline \multicolumn{5}{|l|}{ Variables } \\
\hline Respondents' age (years) & & & & 0.187 \\
\hline $15-19$ & 56.3 & 43.7 & 16 & \\
\hline $20-24$ & 45.8 & 54.2 & 59 & \\
\hline $25-34$ & 48.4 & 51.6 & 254 & \\
\hline $35-49$ & 46.7 & 53.3 & 261 & \\
\hline
\end{tabular}




\begin{tabular}{|c|c|c|c|c|}
\hline $50-64$ & 30.8 & 69.2 & 52 & \\
\hline Education & & & & $<0.0001$ \\
\hline No formal education & 23.1 & 76.9 & 52 & \\
\hline Below secondary & 36.9 & 63.1 & 203 & \\
\hline Secondary and higher & 54.3 & 45.7 & 387 & \\
\hline Locality & & & & $<0.0001$ \\
\hline Rural & 39.4 & 60.6 & 398 & \\
\hline Urban & 57.4 & 42.6 & 244 & \\
\hline Religion & & & & 0.813 \\
\hline Islam & 44.5 & 55.5 & 191 & \\
\hline Christian (Catholic and Protestant) & 47.2 & 52.8 & 424 & \\
\hline Others & 44.4 & 55.6 & 27 & \\
\hline Ethnicity & & & & 0.03 \\
\hline Hausa & 39.1 & 60.9 & 46 & \\
\hline Igbo & 46.8 & 53.2 & 62 & \\
\hline Yoruba & 55 & 45 & 191 & \\
\hline Others & 42.3 & 57.7 & 343 & \\
\hline Alcohol intake & & & & 0.484 \\
\hline Every day & 43.8 & 56.2 & 89 & \\
\hline Sometimes & 49.1 & 50.9 & 267 & \\
\hline Never & 44.4 & 55.6 & 286 & 55.6 \\
\hline $\begin{array}{l}\text { Away from home for more than } 1 \text { month in } \\
\text { the last } 12 \text { months }\end{array}$ & & & & 0.037 \\
\hline Yes & 42.7 & 57.3 & 370 & \\
\hline No & 51.1 & 48.9 & 272 & \\
\hline \multicolumn{5}{|l|}{ Motivation variables } \\
\hline Self-assessment/appraisal of contracting HIV & & & & 0.513 \\
\hline High risk & 41 & 59 & 39 & \\
\hline Others & 46.6 & 53.4 & 603 & \\
\hline
\end{tabular}




\begin{tabular}{|c|c|c|c|c|}
\hline $\begin{array}{l}\text { Condom protects against STI/HIV and } \\
\text { prevents unwanted pregnancy }\end{array}$ & & & & $<0.0001$ \\
\hline Agreed & 51.2 & 48.8 & 541 & \\
\hline Disagreed & 19.8 & 80.2 & 101 & \\
\hline Are you embarrassed to buy condoms? & & & & $<0.0001$ \\
\hline Not embarrassed & 52.1 & 47.9 & 401 & \\
\hline Embarrassed & 36.5 & 63.5 & 241 & \\
\hline Misconception about HIV transmission & & & & 0.004 \\
\hline Yes & 40.8 & 59.2 & 338 & \\
\hline No & 52.3 & 47.7 & 304 & \\
\hline \multicolumn{5}{|l|}{ Opportunity variables } \\
\hline Condom affordability & & & & $<0.0001$ \\
\hline Agreed & 53.2 & 46.8 & 536 & \\
\hline Disagreed & 11.3 & 88.7 & 106 & \\
\hline Condoms easy to obtain & & & & $<0.0001$ \\
\hline Agreed & 52.6 & 47.4 & 519 & \\
\hline Disagreed & 19.5 & 80.5 & 123 & \\
\hline Know how to wear a condom? & & & & $<0.0001$ \\
\hline Yes & 62.7 & 37.3 & 445 & \\
\hline No & 9.1 & 90.9 & 197 & \\
\hline \multicolumn{5}{|l|}{ Ability variables } \\
\hline Know someone who died of AIDS & & & & 0.108 \\
\hline Yes & 51.7 & 48.3 & 172 & \\
\hline No & 44.3 & 55.7 & 470 & \\
\hline Know that AIDS has no cure & & & & 0.012 \\
\hline Yes & 48.6 & 51.4 & 529 & \\
\hline No & 35.4 & 64.6 & 113 & \\
\hline $\begin{array}{l}\text { Know that healthy-looking persons can be } \\
\text { HIV-positive }\end{array}$ & & & & $<0.0001$ \\
\hline
\end{tabular}




\begin{tabular}{|c|c|c|c|c|}
\hline Yes & 50.8 & 49.2 & 510 & \\
\hline No & 28.8 & 71.2 & 132 & \\
\hline \multicolumn{5}{|l|}{ UNAIDS } \\
\hline $\begin{array}{l}\text { Condom use and remain with one uninfected } \\
\text { partner }\end{array}$ & & & & $<0.0001$ \\
\hline Yes & 51.9 & 48.1 & 503 & \\
\hline No & 25.9 & 74.1 & 139 & \\
\hline Discussed condom with partner? & & & & $<0.0001$ \\
\hline Yes & 69 & 31 & 381 & \\
\hline No & 13 & 87 & 261 & \\
\hline Can convince partner to use condom? & & & & $<0.0001$ \\
\hline Yes & 60.7 & 39.3 & 460 & \\
\hline No & 9.9 & 90.1 & 182 & \\
\hline $\begin{array}{l}\text { Abbreviations: AIDS, acquired immunodefi } \\
\text { Virus infection; STI, sexually transmitted infec }\end{array}$ & ncy & e; HI & nan & anodefic \\
\hline
\end{tabular}

(Ankomah A. et al 2013) 
Table 3. Prevalence of Male Circumcision by Sociodemographic Characteristics, 201 I

\begin{tabular}{|c|c|c|c|c|}
\hline \multirow[b]{2}{*}{ Characteristics } & \multicolumn{2}{|c|}{ Male circumcision; n (\%) } & \multirow[b]{2}{*}{ Total } & \multirow[b]{2}{*}{$\chi^{2} P$ value } \\
\hline & Yes & No & & \\
\hline \multicolumn{5}{|c|}{ Age-group (years) } \\
\hline$<20$ & $34(97.1)$ & I (2.9) & $35(100.0)$ & \\
\hline $20-29$ & $99(97.1)$ & $3(2.9)$ & $102(100.0)$ & \\
\hline $30-39$ & $158(98.1)$ & $3(1.9)$ & $161(100.0)$ & \\
\hline$\geq 40$ & $77(100.0)$ & - & $77(100.0)$ & \\
\hline Total & $368(98.1)$ & $7(1.9)$ & $375(100.0)$ & $.26^{\mathrm{a}}$ \\
\hline \multicolumn{5}{|l|}{ Religion } \\
\hline Muslim & $330(98.2)$ & $6(1.8)$ & $336(100.0)$ & \\
\hline Christian & $38(97.4)$ & I (2.6) & $39(100.0)$ & \\
\hline Total & $368(98.1)$ & $7(1.9)$ & $375(100.0)$ & .73 \\
\hline \multicolumn{5}{|l|}{ Ethnicity } \\
\hline Hausa & $228(98.3)$ & $4(1.7)$ & $232(100.0)$ & \\
\hline Fulani & $70(98.6)$ & $\mathrm{I}(1.4)$ & $71(100.0)$ & \\
\hline Yoruba & $25(98.2)$ & I (3.8) & $26(100.0)$ & \\
\hline Igbo & $11(100.0)$ & - & II (100.0) & \\
\hline Others & $34(97.1)$ & I (2.9) & $35(100.0)$ & \\
\hline Total & $368(98.1)$ & $7(1.9)$ & $375(100.0)$ & $.62^{2}$ \\
\hline \multicolumn{5}{|l|}{ Marital status } \\
\hline Single & $354(98.1)$ & $7(1.9)$ & $361(100.0)$ & \\
\hline Ever married & $14(100.0)$ & - & $14(100.0)$ & \\
\hline Total & $368(98.1)$ & $7(1.9)$ & $375(100.0)$ & \\
\hline
\end{tabular}

a. Fisher exact after converting to $2 \times 2$ tables.Age-groups were recategorized into $<30$ and $\geq 30$ years while Hausa and Fulani were merged. Other Nigerian tribes were also placed in one category.

Illiyasu Z et al (2012)

Table 5: Knowledge and Prevalence of FGM

\begin{tabular}{|c|c|c|c|c|c|}
\hline \multirow[t]{2}{*}{ Zone } & \multirow{2}{*}{$\begin{array}{l}\text { Percentage of women } \\
\text { who heard of FGM }\end{array}$} & \multirow{2}{*}{$\begin{array}{l}\text { Percentage of women } \\
\text { circumcised }\end{array}$} & \multicolumn{3}{|c|}{ Types of circumcision } \\
\hline & & & Type 1 & Type 2 & Type 3 \\
\hline North Central & 36.0 & 9.6 & 1.2 & 64.6 & 2.5 \\
\hline North East & 40.1 & 1.3 & - & - & - \\
\hline North West & 25.1 & 0.4 & - & - & - \\
\hline South East & 87.1 & 40.8 & 0.3 & 12.2 & 2.7 \\
\hline South south & 82.5 & 34.7 & 3.0 & 66.0 & 7.5 \\
\hline South West & 85.7 & 56.9 & 2.2 & 36.3 & 1.3 \\
\hline
\end{tabular}




\section{REFERENCES}

Adebajo, SB, Mafeni, J, Moreland, S, Murray, N 2002 'Armed Forces Programmes on AIDS Control (AFPAC): Knowledge, attitudes, and sexual behavior among Nigerian military concerning HIV/AIDS and STD'. Final Technical Report by Policy Project/Nigeria 2002. Available from: http://www.ncbi.nlm.nih.gov/pmc/articles/PMC449717/>

Agaba, PA, Meloni, ST, Sule, HM, Agbaji, OO, Ekeh, PN, Job, GC, Nyango, N, Ugoagwu, PO, Imade, GE, Idoko, JA, Kanki, PJ 2014 'Patients who present late to HIV care and associated risk factors in Nigeria. HIV Medicine (2014), 15, 396-405

Aisien, AO, Shobowale, MO 2005 'Healthcare workers' knowledge on HIV and AIDS: Universal precautions and attitude towards PLWHA in Benin-City Nigeria', Nigerian Journal of clinical practice, Dec. 2005: vol. 8(2). 74-82.

Akhigbe, RE, Bamidele, JO, Abodunrin, OL. 2010 'Seroprevalence of HIV infection in Kwara, Nigeria', Int J Virol., vol. 6, pp. 158-63.

Akpabio, II, Uyanah, DA, Osuchukwu, N, Samson-Akpan, PE 2010 'Influence of marital and educational status on clients' psychosocial adjustment to HIV/AIDS in Calabar, Nigeria', Nursing and Health Sciences (2010), 12, 155-16155

Allman, D, Adebajo, S, Myers, T, Odumuye, O, Ogunsela, S 2007 'Challenges for the sexual health and social acceptance of men who have sex with men in Nigeria', Cultural, health \& sexuality, March-April 2007; 9(2): 153-168

Aniebue, PN \& Aniebue, UU 2011 'Voluntary Counseling and Willingness to Screen among Nigerian Long Distance Truck Drivers', Niger Med J., vol. 52(1), Jan-March, pp. 49-54.

Ankomah, A, Adebayo, SB, Anyanti, J, Ladipo, O, Ekweremadu, B, 2013 'Determinants of condom use by men in extramarital relationships in Nigeria', HIV AIDS (Auckl) v.5, Published online, vol. 5, May, pp. 97-109.

Anyanti, J, Ankomah, A, Mamman-Daura, F, Omoregie, G 2003 'Using sex workers as researcher to assess condom use rates in brothels in Nigeria', Society for Family Health, XV International AIDS Conference, Bangkok, Thailand, July 11-16, 2004 (C2004 by MEDIMOND S.r.l. E710L7501

Azuonwu, O, \& Obire, OE, 2012 'HIV among military personnel in the Niger Delta of Nigeria', $J$ Community Health (2012) 37:25-31, DOI 10.1007/s10900-011-9411-5

Balogun M, \& Odeyemi K 2010 'Knowledge and practice of prevention of mother-to-child transmission of HIV among traditional birth attendants in Lagos, Nigeria', The Pan African Medical Journal - ISSN 1937-8688

Canning, D, Mahal, A, Odumosu, K, Okowkwo, P 2006 'Assessing the Economic Impact of HIV/AIDS on Nigerian Households: viewed 1 October 2013, < http://www.ncbi.nlm.nih.gov/pubmed/18664961>

Dahlgren, G, \& Whitehead, M 1991, 'Determinants of health model', viewed 27 September 2013, http://www.nwci.ie/download/pdf/determinants_health_diagram.pdf 
Desilva, MB, Merry, SP, Fischer, PR, Rohrer, JE, Isichei, CO Cha, SS 2008 'Youth, unemployment, and male gender predict mortality in AIDS patients started on HAART in Nigeria', AIDS Care: Psychological and Socio-medical Aspects of AIDS/HIV, 21:1, 70-77, DOI: 10.1080/09540120802017636

Federal Ministry of Health [Nigeria] 2008, 'National HIV/AIDS and Reproductive Health Survey, 2007 (NARHS Plus', Federal Ministry of Health, Abuja, Nigeria.

FGN 2009 National Policy on HIV/AIDS, Viewed 15 January 2015, $<$ http:// nigeria.unfpa.org/pdf/ntpol.pdf $>$

FGN 2013 National AIDS spending assessment 2007-2008, level and flow of resources and expenditures of the national HIV and AIDS response. Viewed 13 October 2014, < http://www.unaids.org/en/media/unaids/contentassets/dataimport/pub/report/2008/NASA N igeria 2007-2008 en.pdf>

FHI 2005 Workplace HIV/AIDS programs available at http://data.unaids.org/pub/BaseDocument/2004/workplacefhi en.pdf

IBBSS 2010, Nigeria Integrated Biological and Behavioural Surveillance Survey 2010', viewed 3 October 2014, http://www.popcouncil.org/pdfs/2011HIV_IBBSS2010.pdf

Illiyasu, Z, Abubakar, IS, Sani, IH, Jibo AM, Karaye, IM, Salihu, HM, Aliyu, MH, 2012 Male Circumcision and HIV Risk Behavior Among University Students in Northern Nigeria' Am J Mens Health March 2013 vol. 7 no. 2 94-101, viewed 1 October 2013, $<$ http://jmh.sagepub.com/content/7/2/94.full\#T3>

Mahal, A, Canning, D, Odumosu, K, Okonkwo, P 2008 Assessing the economic impact of HIV/AIDS on Nigeria households: a propensity score matching approach, AIDS 2008, 22 (suppl 1):S95-S101

Mbonu, NC, Borne, BVD, Vries, NKD, 2010, 'Gender-related power differences, beliefs and reactions towards people living with HIV/AIDS: an urban study in Nigeria' BMC Public Health, vol. 10, June, pp. 334.

Monjok, E, Essien, EJ, Laurens, H 2007 'Female genital mutilation: potential for HIV transmission in Sub-Saharan Africa and prospect for epidemiologic investigation and intervention', 35 African Journal of Reproductive Health Vol. 11 No. 1 April, 2007.

Muhammad, T, Usman, A, Baba, MM, Thilza, IB, 2010 HIV infection among male prison inmates in Abuja Nigeria. [Researcher. 2010, 2(3): 28-30] (ISSN: 1553-9865)

NACA 2005, Nigeria HIV AIDS National strategic Framework for Action (2005-2009)', Society for Family Health, viewed 27 September 2013, < http://www.aidstarone.com/sites/default/files/prevention/resources/national_strategic_plans/Nigeria_05-09.pdf>

NACA 2009 National HIV/AIDS policy review report: Report of desk review and stakeholders' interaction. Available at < http://hivhealthclearinghouse.unesco.org/sites/default/files/resources/iiep_nigeria_national_poli cy_review_report_2009.pdf> 
NARHS Plus II 2012 National HIV/AIDS and Reproductive Health Survey (NARHS Plus II 2012, Federal Republic of Nigeria Federal Ministry of Health Abuja, Nigeria. Viewed 13 October 2014, http://nascp.gov.ng/demo/wp-content/uploads/2014/02/NARHS-Plus-2012-Final18112013.pdf

National Population Commission (NPC) [Nigeria] and ICF Macro. 2009. Nigeria Demographic and Health Survey <http://www.measuredhs.com>

NDHS 2008, Demographic and Health Survey' viewed 26 September 2013 <http://www.measuredhs.com/pubs/pdf/SR173/SR173.pdf>.

NPC 2006, 'National Population Commission (NPC) [Nigeria] 2006, 'Final results of 2006 Census Abuja, Nigeria', viewed on 27 September 2013, <_www.population.gov.ng>

NSP 2010-2015, 2010 National HIV/AIDS Strategic Plan (2010-2015),' viewed 1 October 2013, viewed 3 October 2013, <http://www.aidstarone.com/sites/default/files/prevention/resources/national_strategic_plans/Nigeria_2010-

15.pdf>, <http://nigeria.unfpa.org/pdf/nsp.pdf>

Obi, SN, Ifebunandu, NA, Onyebuchi, AK, 2010, 'Nutritional status of HIV-positive individuals on free HAART treatment in a developing nation', J Infect Dev Ctries 2010; 4(11):745-749, viewed 1 October 2013, <www.jidc.org/index.php/journal/article/download/21252453/46>

PEPFAR 2012, Nigeria operational plan report FY 2012', viewed 30 September 2013, <http://www.pepfar.gov/documents/organization/212153.pdf>

Reis, C, Heisler, M, Amowitz, LL, Moreland, RS, Mafeni, JO, Anyamele, C, Lacopino, V 2005 'Discriminatory Attitudes and Practices by Health Workers toward Patients with HIV/AIDS in Nigeria', PLOS Medicine, viewed $30 \quad$ September 2013, < http://www.plosmedicine.org/article/info\%3Adoi\%2F10.1371\%2Fjournal.pmed.0020246>

Report on the Global AIDS Epidemic (2006) 'Geneva, Switzerland: Joint United Nations Programme on HIV/AIDS' $\quad$ viewed $28 \quad$ September $2013, \quad<$ http://www.unaids.org/en/media/unaids/contentassets/dataimport/pub/globalreport/2008/jc1 510_2008globalreport_en.pdf >

Risley, CL, Drake, LJ, Bundy, DAP 2012 Economic Impact of HIV and Antiretroviral Therapy on Education Supply in High Prevalence Regions. PLoS ONE 7(11): e42909. doi:10.1371/journal.pone.0042909

Sunmola, AM (2010) Sexual practices, barriers to condom use and its consistent use among long distance truck drivers in Nigeria, AIDS Care: Psychological and Sociomedical Aspects of AIDS/HIV, 17:2, 208-221, DOI: 10.1080/09540120512331325699

Ugwu, DS 2009, 'Socio-Economic Impact of HIV/AIDS on farm women in Nigeria: Evidence from Enugu State; World Applied Sciences Journal 6 (12): 1617-1624, 2009, viewed 2 October 2013, < http://www.idosi.org/wasj/wasj6\%2812\%29/5.pdf>

UNAIDS 2010, 'Report on the Global AIDS Epidemic 2010', viewed 30 September 2013, < http://www.slideshare.net/unaids/unaids-report-on-the-global-aids-epidemic-2010> 
UNIADS 2012, 'Know your Country Progress Report 2012' viewed 26 September 2013, <http://www.unaids.org/en/dataanalysis/knowyourresponse/countryprogressreports/2012count ries/Nigeria\%202012\%20GARPR\%20Report $\% 20$ Revised.pdf>

UNICEF 2010, Nigeria: Female genital Mutilation available from: http://www.unicef.org/nigeria/FGM .pdf

Weine, SM, Kashuba, AB 2012, 'Labor Migration and HIV Risk: A Systematic Review of the Literature' National Institute of Health. viewed 30 September 2013, < http://link.springer.com/article/10.1007/s10461-012-0183-4\#page-1>

WHO 2006 'Strategies Strategies and Approaches for Male Circumcision Programming - WHO Meeting Report, 5-6 December 2006, Geneva.' Available from: < http://whqlibdoc.who.int/publications/2007/9789241595865_eng.pdf>

WHO 2013, 'Female genital mutilation', viewed 1 October 2013, <http://www.who.int/mediacentre/factsheets/fs241/en/>

WHO/UNAIDS 2006 'AIDS epidemic update; special report on HIV/AIDS. WHO/UNAIDS' viewed $28 \quad$ September 2013, < http://www.unaids.org/en/media/unaids/contentassets/dataimport/pub/report/2006/2006 gr en.pdf $>$ 